Article

\title{
Impact of Changes in Serum Calcium Levels on In-Hospital Mortality
}

\author{
Charat Thongprayoon ${ }^{1, *}$, Wisit Cheungpasitporn ${ }^{2, *}\left(\mathbb{D}\right.$, Panupong Hansrivijit ${ }^{3}$, Juan Medaura ${ }^{2}$,

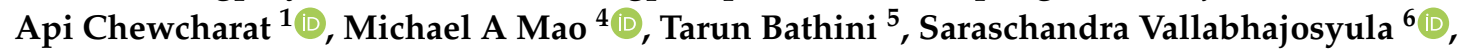 \\ Sorkko Thirunavukkarasu ${ }^{1}$ and Stephen B. Erickson ${ }^{1}$ \\ 1 Division of Nephrology and Hypertension, Department of Medicine, Mayo Clinic, Rochester, MN 55905, \\ USA; api.che@hotmail.com (A.C.); Thirunavukkarasu.Sorkko@mayo.edu (S.T.); \\ Erickson.Stephen@mayo.edu (S.B.E.) \\ 2 Division of Nephrology, Department of Internal Medicine, University of Mississippi Medical Center, Jackson, \\ MS 39216, USA; jmedaura@umc.edu \\ 3 Department of Internal Medicine, University of Pittsburgh Medical Center Pinnacle, Harrisburg, PA 17101, \\ USA; p.hansrivijit@gmail.com \\ 4 Division of Nephrology and Hypertension, Mayo Clinic, Jacksonville, FL 32224, USA; \\ mao.michael@mayo.edu \\ 5 Department of Internal Medicine, University of Arizona, Tucson, AZ 85721, USA; tarunjacobb@gmail.com \\ 6 Department of Cardiovascular Medicine, Mayo Clinic, Rochester, MN 55905, USA; \\ Vallabhajosyula.Saraschandra@mayo.edu \\ * Correspondence: charat.thongprayoon@gmail.com (C.T.); wcheungpasitporn@gmail.com (W.C.); \\ Tel.: +1-(507)-266-7961 (C.T.); Fax: +1-(507)-266-7891 (C.T.)
}

Received: 20 February 2020; Accepted: 28 February 2020; Published: 2 March 2020

\begin{abstract}
Background and objectives: Calcium concentration is strictly regulated at both the cellular and systemic level, and changes in serum calcium levels can alter various physiological functions in various organs. This study aimed to assess the association between changes in calcium levels during hospitalization and mortality. Materials and Methods: We searched our patient database to identify all adult patients admitted to our hospital from January 1st, 2009 to December 31st, 2013. Patients with $\geq 2$ serum calcium measurements during the hospitalization were included. The serum calcium changes during the hospitalization, defined as the absolute difference between the maximum and the minimum calcium levels, were categorized into five groups: $0-0.4,0.5-0.9,1.0-1.4$, $1.5-1.9$, and $\geq 2.0 \mathrm{mg} / \mathrm{dL}$. Multivariable logistic regression was performed to assess the independent association between calcium changes and in-hospital mortality, using the change in calcium category of $0-0.4 \mathrm{mg} / \mathrm{dL}$ as the reference group. Results: Of 9868 patients included in analysis, $540(5.4 \%)$ died during hospitalization. The in-hospital mortality progressively increased with higher calcium changes, from $3.4 \%$ in the group of $0-0.4 \mathrm{mg} / \mathrm{dL}$ to $14.5 \%$ in the group of $\geq 2.0 \mathrm{mg} / \mathrm{dL}(p<0.001)$. When adjusted for age, sex, race, principal diagnosis, comorbidity, kidney function, acute kidney injury, number of measurements of serum calcium, and hospital length of stay, the serum calcium changes of 1.0-1.4, 1.5-1.9, and $\geq 2.0 \mathrm{mg} / \mathrm{dL}$ were significantly associated with increased in-hospital mortality with odds ratio (OR) of 1.55 (95\% confidence interval (CI) 1.15-2.10), 1.90 (95\% CI 1.32-2.74), and 3.23 (95\% CI 2.39-4.38), respectively. The association remained statistically significant when further adjusted for either the lowest or highest serum calcium. Conclusion: Larger serum calcium changes in hospitalized patients were progressively associated with increased in-hospital mortality.
\end{abstract}

Keywords: calcium; electrolytes; hypocalcemia; hypercalcemia; mortality 


\section{Introduction}

Calcium is the most abundant mineral in the human body and has many essential functions including muscle function, nerve transmission, intracellular signaling, and mediating vascular contraction and vasodilatation [1,2]. Furthermore, cardiac contractility is also regulated by changes in intracellular calcium concentration $[3,4]$. Thus, calcium level is strictly regulated at both the cellular and systemic levels [5-7].

Serum calcium levels are affected by several important factors including vitamin D and parathyroid hormone (PTH), serum phosphate, and magnesium levels [5,8-10]. Abnormalities of calcium derangements and changes in serum calcium levels are common in clinical practice, especially among critically ill patients with prevalence up to $88 \%$ [5,10-15]. While a decrease in serum calcium is associated with severity of illness [5,11,12], an increase in serum calcium among hospitalized patients is commonly seen in primary hyperparathyroidism, certain medications, and diseases, such as underlying malignancy [16-18]. Previous studies have demonstrated the impact of serum calcium levels, including hypocalcemia and hypercalcemia, on poor clinical outcomes including mortality among hospitalization $[15,19,20]$. However, little is known about the effects of changes in serum calcium level on outcomes during hospitalization.

Thus, we conducted this study to evaluate the relationship between changes in serum calcium level during hospitalization and mortality in all hospitalized patients.

\section{Materials and Methods}

\subsection{Study Population}

We searched our patient database to identify all adult patients admitted to our hospital from January 1st, 2009 to December 31st, 2013. Patients with at least 2 serum calcium measurements during hospitalization were included. Patients without research authorization were excluded. If patients had recurring admissions, only the first hospitalization during the study period was included in the analysis. This study was reviewed and approved by the Mayo Clinic institutional review board (IRB number: 15-000024; Approval Date: 2/4/2015). The informed consent was waived due to the minimal risk nature of the study.

\subsection{Data Collection}

Clinical information and laboratory data were obtained from our institutional electronic health record system using the Mayo Clinic Life Science System Database. This database contains demographic characteristics, hospital admission information, diagnosis and procedure codes, laboratory test results, and flow sheet data of inpatient admission. Serum calcium change during hospitalization, defined as the absolute difference between the maximum and minimum serum calcium values during hospitalization, was the exposure of interest. Serum calcium change was categorized into 5 groups; 0-0.4, 0.5-0.9, $1.0-1.4,1.5-1.9, \geq 2.0 \mathrm{mg} / \mathrm{dL}$.

To further assess if the direction of serum calcium change was associated with patient outcomes, the timing of the highest serum calcium in relation to the lowest serum calcium was determined. If the highest serum calcium occurred before the lowest serum calcium, a downward trend of serum calcium change was assumed, and negative values for serum calcium change (the lowest to the highest serum calcium) was assigned. In contrast, if the highest serum calcium occurred after the lowest serum calcium, an upward trend of serum calcium change was assumed, and positive values for serum calcium change (the highest to the lowest serum calcium) were assigned. Phosphate change with direction of change was categorized into 10 groups; $\leq-2.0,-1.9$ to $-1.5,-1.4$ to $-1.0,-0.9$ to $-0.5,-0.4$ to $0.0,0.1$ to $0.4,0.5$ to $0.9,1.0$ to $1.4,1.5$ to 1.9 , and $\geq 2.0 \mathrm{mg} / \mathrm{dL}$.

Principal diagnoses were categorized based on International Classification of Diseases, 9th Revision, (ICD-9) codes. The Charlson Comorbidity Score [21] was calculated to assess comorbid conditions at the time of admission. The medical comorbid conditions were collected utilizing a previously validated 
data abstraction algorithm. Estimated glomerular filtration rate (eGFR) was calculated using the Chronic Kidney Disease Epidemiology Collaboration (CKD-EPI) equation [22]. Acute kidney injury (AKI) was defined as an increase in serum creatinine of $\geq 0.3 \mathrm{mg} / \mathrm{dL}$ or $\geq 1.5$ times from the most recent outpatient serum creatinine within 1 year before admission [23].

\subsection{Clinical Outcomes}

In-hospital mortality was the outcome of interest. Death status was obtained from the institutional database.

\subsection{Statistical Analysis}

Continuous variables were presented as mean \pm standard deviation (SD) or median with interquartile range (IQR), as appropriate. The differences in continuous variables between calcium change groups were tested using analysis of variance (ANOVA). Categorical variables were presented as count with percentage. The differences in categorical variables between calcium change groups were tested using Chi-squared test. The serum calcium change group of $0-0.6 \mathrm{mg} / \mathrm{dL}$ was chosen as the reference group for outcome comparison. Logistic regression analysis was conducted to assess the association between serum calcium change during hospitalization and in-hospital mortality. A multivariable model was built to adjust for priori-defined variables. Model 1 was unadjusted; model 2 was adjusted for age, race, sex, principal diagnosis, Charlson Comorbidity Score, history of coronary artery disease, congestive heart failure, peripheral artery disease, stroke, diabetes mellitus, chronic obstructive pulmonary disease, cirrhosis, eGFR, intensive care unit (ICU) admission, AKI occurrence in hospital, the number of serum calcium measurements during hospitalization, and hospital length of stay; model 3 was adjusted for all variables in model 2, plus the lowest serum calcium during hospitalization; model 4 was adjusted for all variables in model 2, plus the highest calcium during hospitalization, and model 5 was adjusted for all variables in model 2, plus the admission calcium. Two-tailed $p$ value $<0.05$ was considered statistically significant. All analyses were performed using JMP statistical software (Version 10; SAS Institute Inc., Cary, NC, USA).

\section{Results}

\subsection{Clinical Characteristics}

A total of 9868 patients were analyzed. Fifty-five percent were male. The mean age was $61 \pm 17$ years. The median number of serum calcium measurements during hospitalization was $3(2-5)$, and length of hospital stay was 7 (4-14) days. Given the normal reference range of total serum calcium of $8.6-10.0 \mathrm{mg} / \mathrm{dL}$ in our hospital, $1501(15 \%)$ had elevated serum calcium above $10.0 \mathrm{mg} / \mathrm{dL}$, and 6481 $(65 \%)$ had decreased serum calcium below $8.6 \mathrm{mg} / \mathrm{dL}$ during the hospitalization. The mean serum calcium change during hospitalization was $1.0 \pm 1.2 \mathrm{mg} / \mathrm{dL}$. The clinical characteristics of patients based on serum calcium change groups are summarized in Table 1. 
Table 1. Clinical characteristics.

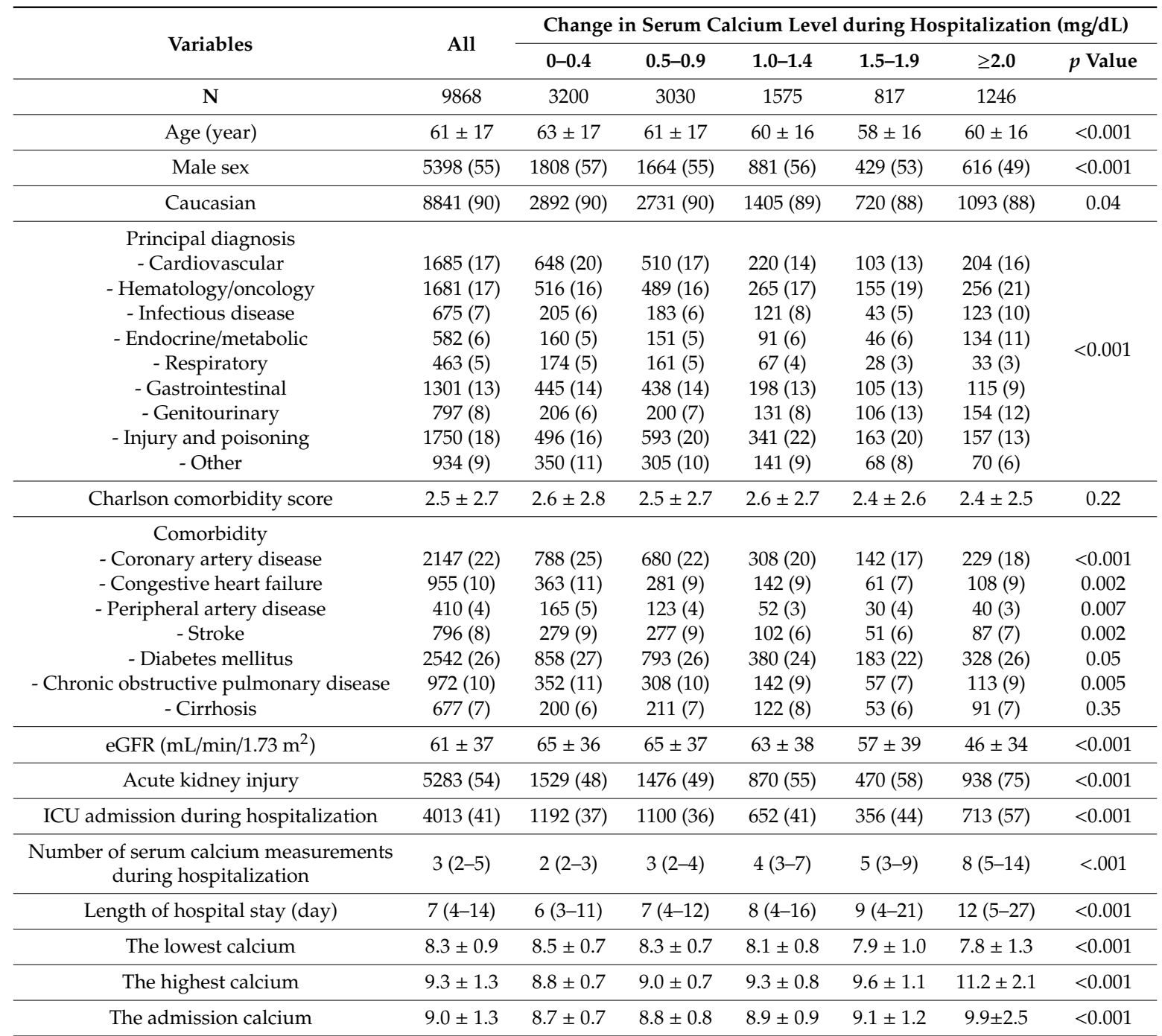

Continuous data are presented as mean \pm SD; categorical data are presented as count (\%); eGFR, estimated glomerular filtration rate; ICU, intensive care unit.

\subsection{Serum Calcium Change and In-Hospital Mortality}

Out of 9868 patients included in the study, 540 (5.5\%) died in hospital. The restricted cubic spline showed the U-shaped association between the direction of serum calcium change and in-hospital mortality (Figure 1). The in-hospital mortality progressively increased with higher calcium change, from $3.4 \%$ in the group of $0-0.4 \mathrm{mg} / \mathrm{dL}$ to $14.5 \%$ in the group of $\geq 2.0 \mathrm{mg} / \mathrm{dL}(p<0.001)$ (Table 2 ). When adjusting for potential confounders (model 2), serum calcium changes of 1.0-1.4, 1.5-1.9, $\geq 2.0 \mathrm{mg} / \mathrm{dL}$ were significantly associated with increased in-hospital mortality with adjusted odds ratio (OR) of 1.55 (95\% CI 1.15-2.10), 1.90 (95\% CI 1.32-2.74), and 3.23 (95\% CI 2.39-4.38), respectively, when compared to the serum calcium change group of $0-0.6 \mathrm{mg} / \mathrm{dL}$. The association remained statistically significant with a serum calcium change of $\geq 1.0 \mathrm{mg} / \mathrm{dL}$ when further adjusting for either the lowest (model 3), or highest serum calcium (model 4). When further adjusting for admission serum calcium (model 5), the serum calcium change of $\geq 1.5 \mathrm{mg} / \mathrm{dL}$ was significantly associated with increases in-hospital mortality. 


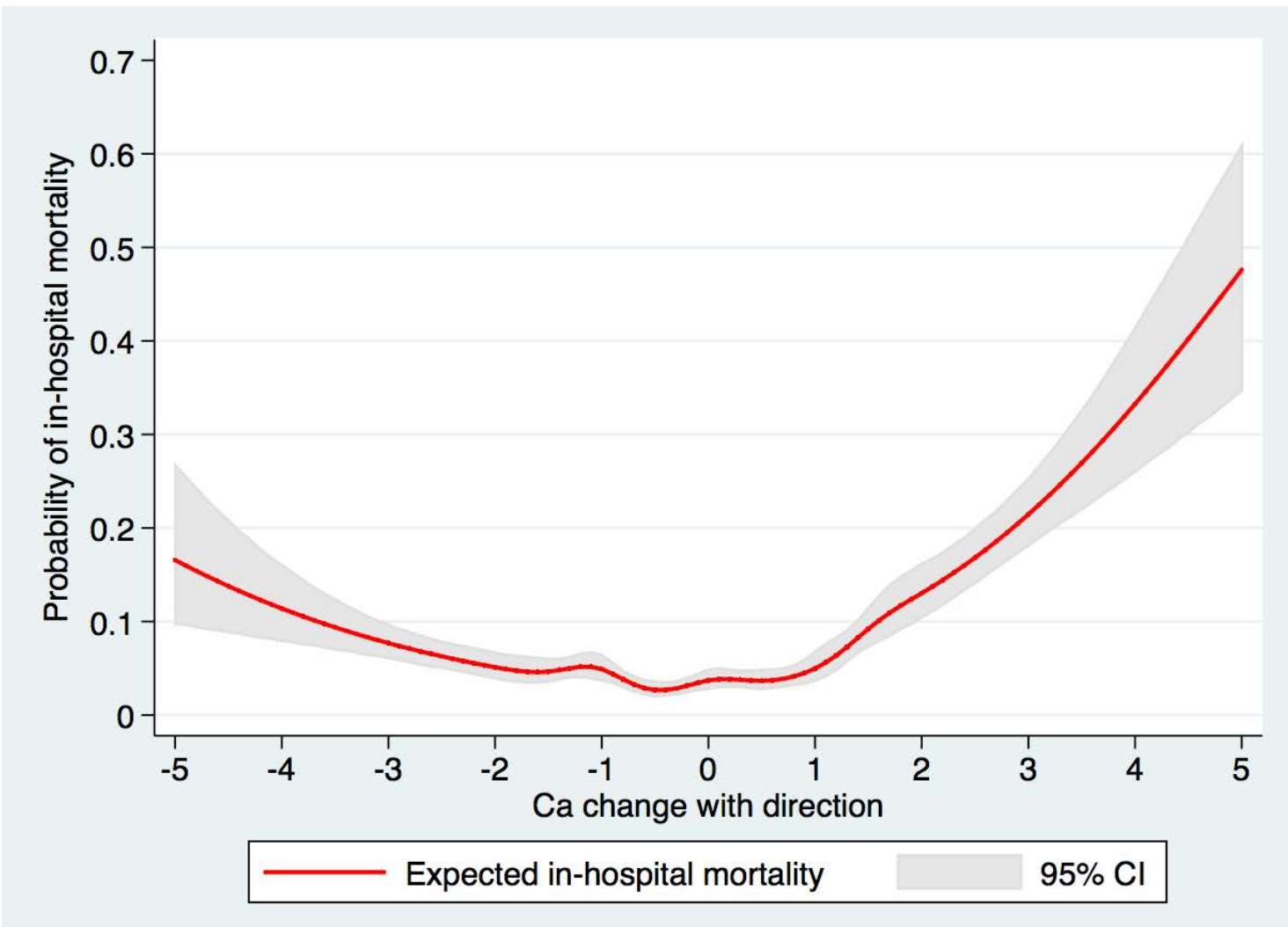

Figure 1. The restricted cubic spline showed the U-shaped association between the direction of serum calcium change and in-hospital mortality. $\mathrm{CI}=$ confidence interval.

Table 2. The association between serum calcium change and in-hospital mortality.

\begin{tabular}{cccccc}
\hline \multirow{2}{*}{ Outcome } & \multicolumn{5}{c}{ Change in Serum Calcium Level during Hospitalization (mg/dL) } \\
\cline { 2 - 6 } & $\mathbf{0 - 0 . 4}$ & $\mathbf{0 . 5 - 0 . 9}$ & $\mathbf{1 . 0}-\mathbf{1 . 4}$ & $\mathbf{1 . 5 - 1 . 9}$ & $\geq \mathbf{2 . 0}$ \\
\hline $\mathrm{N}$ & 3200 & 3030 & 1575 & 817 & 1246 \\
\hline Hospital mortality & $111(3.4)$ & $104(3.4)$ & $91(5.8)$ & $54(6.6)$ & $180(14.5)$ \\
\hline Mortality, OR (95\% CI) & & & & \\
\hline Model 1: unadjusted & 1 (ref) & $0.99(0.75-1.30)$ & $1.71(1.28-2.27)$ & $1.97(1.41-2.75)$ & $4.70(3.67-6.01)$ \\
\hline Model 2 \# & 1 (ref) & $1.04(0.78-1.38)$ & $1.55(1.45-2.10)$ & $1.90(1.32-2.74)$ & $3.23(2.39-4.38)$ \\
\hline Model 3: model 2 and lowest calcium & 1 (ref) & $1.07(0.81-1.43)$ & $1.65(1.22-2.24)$ & $2.04(1.42-2.94)$ & $3.52(2.60-4.78)$ \\
\hline Model 4: model 2 and highest calcium & 1 (ref) & $0.99(0.74-1.31)$ & $1.39(1.02-1.89)$ & $1.58(1.09-2.29)$ & $1.93(1.34-2.79)$ \\
\hline Model 5: model 2 and admission calcium * & 1 (ref) & $1.02(0.71-1.47)$ & $1.32(0.90-1.94)$ & $1.76(1.11-2.79)$ & $2.50(1.67-3.74)$ \\
\hline
\end{tabular}

\# Adjusted for age, sex, race, principal diagnosis, Charlson comorbidities score, history of coronary artery disease, congestive heart failure, peripheral artery disease, stroke, diabetes mellitus, chronic obstructive pulmonary disease, cirrhosis, eGFR, ICU admission, acute kidney injury (AKI), the number of serum calcium measurements during hospitalization, and length of stay. * Analysis was limited to patients with available admission calcium

\subsection{Direction of Serum Calcium Change and In-Hospital Mortality}

The higher in-hospital mortality was observed in both upward and downward trends of serum calcium change (Table 3 and Figure 1). Regarding the downward trend of serum calcium change, serum calcium change of $\leq-2.0 \mathrm{mg} / \mathrm{dL}$ was significantly associated with increased in-hospital mortality. Regarding the upward trend of serum calcium change, serum calcium changes of 1.0 to $1.4,1.5$ to 1.9 , and $\geq 2.0 \mathrm{mg} / \mathrm{dL}$ were significantly associated with increased in-hospital mortality. The OR of in-hospital mortality associated with a markedly upward trend of serum calcium change was higher than the OR of in-hospital mortality associated with a markedly downward trend of serum calcium change. 
Table 3. The association between the direction of serum calcium change and in-hospital mortality.

\begin{tabular}{cccccccc}
\hline $\begin{array}{c}\text { Calcium } \\
\begin{array}{c}\text { Change } \\
\text { (mg/dL) }\end{array}\end{array}$ & N & $\begin{array}{c}\text { In-Hospital } \\
\text { Mortality }\end{array}$ & Model 1 & Model 2 & Model 3 & Model 4 & Model 5 * \\
\hline$\leq-2.0$ & 768 & $66(8.6)$ & $2.72(1.90-3.88)$ & $2.27(1.53-3.39)$ & $2.35(1.58-3.49)$ & $1.32(0.83-2.10)$ & $1.91(1.10-3.31)$ \\
\hline-1.9 to -1.5 & 513 & $21(4.1)$ & $1.23(0.75-2.04)$ & $1.31(0.77-2.20)$ & $1.37(0.81-2.32)$ & $1.09(0.64-1.86)$ & $1.51(0.83-2.74)$ \\
\hline-1.4 to -1.0 & 961 & $52(5.4)$ & $1.65(1.13-2.41)$ & $1.58(1.07-2.34)$ & $1.65(1.12-2.45)$ & $1.42(0.96-2.10)$ & $1.42(0.88-2.29)$ \\
\hline-0.9 to -0.5 & 1764 & $55(3.1)$ & $0.93(0.64-1.34)$ & $0.96(0.66-1.40)$ & $0.98(0.68-1.43)$ & $0.91(0.62-1.32)$ & $1.06(0.68-1.66)$ \\
\hline-0.4 to 0.0 & 1885 & $63(3.3)$ & $1($ ref $)$ & $1($ ref $)$ & $1($ ref $)$ & $1($ ref $)$ & $1($ ref $)$ \\
\hline 0.1 to 0.4 & 1316 & $48(3.7)$ & $1.09(0.75-1.60)$ & $1.05(0.71-1.55)$ & $1.07(0.72-1.58)$ & $1.06(0.72-1.57)$ & $0.95(0.57-1.60)$ \\
\hline 0.5 to 0.9 & 1266 & $49(3.9)$ & $1.16(0.80-1.70)$ & $1.14(0.77-1.68)$ & $1.19(0.81-1.77)$ & $1.11(0.75-1.65)$ & $0.93(0.55-1.60)$ \\
\hline 1.0 to 1.4 & 614 & $39(6.4)$ & $1.96(1.30-2.96)$ & $1.93(1.26-2.96)$ & $2.10(1.36-3.23)$ & $1.82(1.19-2.80)$ & $1.79(1.03-3.11)$ \\
\hline 1.5 to 1.9 & 304 & $33(10.9)$ & $3.52(2.27-5.47)$ & $3.72(2.33-5.95)$ & $4.05(2.52-6.49)$ & $3.23(2.01-5.20)$ & $3.27(1.74-6.16)$ \\
\hline$\geq 2.0$ & 477 & $114(23.9)$ & $9.08(6.54-12.60)$ & $7.40(5.08-10.78)$ & $8.44(5.74-12.41)$ & $5.07(3.36-7.64)$ & $6.28(3.82-10.32)$ \\
\hline
\end{tabular}

Model 1: Unadjusted; Model 2: Adjusted for age, sex, race, principal diagnosis, Charlson comorbidities score, history of coronary artery disease, congestive heart failure, peripheral artery disease, stroke, diabetes mellitus, chronic obstructive pulmonary disease, cirrhosis, eGFR, ICU admission, AKI, the number of serum calcium measurements during hospitalization, and length of stay; Model 3: model 2 and the lowest serum calcium; Model 4: model 2 and the highest serum calcium; Model 5: model 2 and the admission calcium; ${ }^{*}$ Analysis was limited to patients with available admission calcium. Abbreviations: $\mathrm{CI}=$ confidence interval; $\mathrm{OR}=$ odds ratio.

\section{Discussion}

In this study, we demonstrated that the changes in serum calcium level during hospitalization were associated with hospital mortality. Patients with changes in serum calcium level $>1.0 \mathrm{mg} / \mathrm{dL}$ were associated with increased risk of mortality, while the highest mortality was observed among patients with calcium change $\geq 2 \mathrm{mg} / \mathrm{dL}$ during hospitalization. We observed the higher in-hospital mortality in both upward $(\geq 1.0 \mathrm{mg} / \mathrm{dL})$ and downward $(\leq-2.0 \mathrm{mg} / \mathrm{dL})$ trends of serum calcium change.

Previous studies have demonstrated the impacts of admission hypocalcemia and hypercalcemia on hospital mortality $[15,19]$. In this study, we demonstrated adverse effects of changes in serum calcium during hospitalization on mortality, while patients with stable serum calcium level during hospitalization had the lowest hospital mortality. Decrease in serum calcium is common among critically ill patients and correlates with severity of illness [5,11,12]. Furthermore, reduction in serum calcium can occur after blood transfusions, plasma exchanges, and parathyroidectomy [24-26]. In this study, we comprehensively adjusted for all identifiable factors including comorbidities, and revealed a significant association of decrease in serum calcium $(\leq-2.0 \mathrm{mg} / \mathrm{dL})$ during hospitalization with higher in-hospital mortality. Although the underlying mechanisms remain unclear, it is suggested that decrease in serum calcium can significantly alter the myocardium action potential and reduce renal sodium excretion resulting in fluid overload and reduced contractility [10,27-31].

Our study demonstrated that the risk of in-hospital mortality is markedly high with an upward trend of serum calcium change than the risk of in-hospital mortality in patients with a downward trend of serum calcium change. An increase in serum calcium level is frequently seen among hospitalized patients with principal diagnoses of hematologic/oncological diseases and endocrine/metabolic disorders $[15,19,32]$. A rise in serum calcium may enhance atherogenesis through vascular calcification and increased coagulability [33]. An increase in serum calcium is associated with incident heart failure [33] and possible hypercalcemia-induced neuronal injury among patients with acute ischemic stroke [34]. Moreover, an increase in serum calcium may result in AKI via renal vasoconstriction and nephrogenic diabetes insipidus-induced volume depletion [35-40]. In our current study, we also adjusted AKI during hospitalization in our multivariable logistic regression analysis, and we found that the upward trend of serum calcium change of $>1.0 \mathrm{mg} / \mathrm{dL}$ was significantly associated with increased in-hospital mortality, while the highest mortality (6.3-fold increased mortality) was observed in patients with an absolute increase in serum calcium level $\geq 2.0 \mathrm{mg} / \mathrm{dL}$. 
There are some limitations to our study. First, this is a single-center retrospective cohort study conducted in a predominantly Caucasian population. This potentially limited generalizability of the study. Due to the observational nature of the study, the causal association cannot be established. In addition, the data from this study were retrieved from institutional database. Unfortunately, some clinical information such as treatment of abnormalities of calcium derangements, oral calcium supplement, intravenous calcium infusion, complete data on other electrolytes [41-46], and medications was not available in our database and, therefore, was not reported in this study. Although we extensively adjusted for potential confounders, the association between serum calcium change and mortality might remain be confounded by unmeasured confounders. Future study with a more diversified population and more comprehensive clinical information is needed to better assess the association. Second, we did not use albumin-corrected serum calcium in the analysis because of limited availability of serum albumin at the time of serum calcium measurement. Lastly, our study only addresses the impact of magnitude and direction of serum calcium change on mortality; other aspects of serum calcium change such as acuity and variability were not assessed. These factors are also important for the understanding of the impact of serum calcium change and patient outcomes.

\section{Conclusions}

In conclusion, we demonstrated that the absolute change of serum calcium during admission is associated with increased in-hospital mortality. The association progressively increases with the degree of serum calcium change. A downward trend of serum calcium change $(\leq-2.0 \mathrm{mg} / \mathrm{dL})$ and an upward trend of serum calcium change $\geq 1.0 \mathrm{mg} / \mathrm{dL}$ were significantly associated with increased in-hospital mortality.

Author Contributions: Conceptualization, C.T., W.C., M.A.M. and S.B.E.; Data curation, C.T.; Formal analysis, C.T.; Investigation, C.T. and W.C.; Methodology, C.T., W.C., J.M. and M.A.M.; Project administration, P.H., A.C., T.B., S.T. and S.B.E.; Resources, T.B.; Software, C.T.; Supervision, W.C., M.A.M., S.V. and S.B.E.; Validation, W.C.; Visualization, W.C. and T.B.; Writing—original draft, C.T.; Writing—review \& editing, C.T., W.C., P.H., J.M., A.C., M.A.M., T.B., S.T. and S.B.E. All authors have read and agreed to the published version of the manuscript.

Conflicts of Interest: The authors have declared that no competing interests exist.

\section{References}

1. Beto, J.A. The Role of Calcium in Human Aging. Clin. Nutr. Res. 2015, 4, 1-8. [CrossRef]

2. Thongprayoon, C.; Cheungpasitporn, W.; Chewcharat, A.; Mao, M.A.; Thirunavukkarasu, S.; Kashani, K. Hospital mortality and long-term mortality among hospitalized patients with various admission serum ionized calcium levels. Postgrad. Med. 2020, 1-6. [CrossRef]

3. Eisner, D.A.; Caldwell, J.; Kistamás, K.; Trafford, A.W. Calcium and Excitation-Contraction Coupling in the Heart. Circ. Res. 2017, 121, 181-195. [CrossRef] [PubMed]

4. McClellan, G.; Kulikovskaya, I.; Winegrad, S. Changes in cardiac contractility related to calcium-mediated changes in phosphorylation of myosin-binding protein C. Biophys. J. 2001, 81, 1083-1092. [CrossRef]

5. Collage, R.D.; Howell, G.M.; Zhang, X.; Stripay, J.L.; Lee, J.S.; Angus, D.C.; Rosengart, M.R. Calcium Supplementation During Sepsis Exacerbates Organ Failure and Mortality via Calcium/Calmodulin-Dependent Protein Kinase Kinase Signaling. Crit. Care Med. 2013, 41, e352-e360. [CrossRef] [PubMed]

6. Lü, X.; Wang, Y.; Meng, H.; Chen, P.; Huang, Y.; Wang, Z.; Zhou, N.; Li, C.; Wang, L.; Jia, E.; et al. Association of Admission Serum Calcium Levels and In-Hospital Mortality in Patients with Acute ST-Elevated Myocardial Infarction: An Eight-Year, Single-Center Study in China. PLoS ONE 2014, 9, e99895.

7. Bushinsky, D.A.; Monk, R.D. Electrolyte quintet: Calcium. Lancet 1998, 352, 306-311. [CrossRef]

8. Michaelsson, K.; Melhus, H.; Lemming, E.W.; Wolk, A.; Byberg, L. Long term calcium intake and rates of all cause and cardiovascular mortality: Community based prospective longitudinal cohort study. BMJ 2013, 346, f228. [CrossRef]

9. Yan, S.-D.; Liu, X.; Peng, Y.; Xia, T.-L.; Liu, W.; Tsauo, J.-Y.; Xu, Y.; Chai, H.; Huang, F.-Y.; Chen, M.; et al. Admission Serum Calcium Levels Improve the GRACE Risk Score Prediction of Hospital Mortality in Patients With Acute Coronary Syndrome. Clin. Cardiol. 2016, 39, 516-523. [CrossRef] 
10. Miura, S.; Yoshihisa, A.; Takiguchi, M.; Shimizu, T.; Nakamura, Y.; Yamauchi, H.; Iwaya, S.; Owada, T.; Miyata, M.; Abe, S.; et al. Association of Hypocalcemia With Mortality in Hospitalized Patients With Heart Failure and Chronic Kidney Disease. J. Card. Fail. 2015, 21, 621-627. [CrossRef]

11. Zivin, J.R.; Gooley, T.; Zager, R.A.; Ryan, M.J. Hypocalcemia: A pervasive metabolic abnormality in the critically ill. Am. J. Kidney Dis. 2001, 37, 689-698. [CrossRef]

12. Israel, R. Prevalence and clinical implications of hypocalcemia in acutely ill patients in a medical intensive care setting. J. Emerg. Med. 1988, 6, 558. [CrossRef]

13. Müller, B.; Becker, K.L.; Kränzlin, M.; Schächinger, H.; Huber, P.R.; Nylen, E.S.; Snider, R.H.; White, J.C.; Schmidt-Gayk, H.; Zimmerli, W.; et al. Disordered calcium homeostasis of sepsis: Association with calcitonin precursors. Eur. J. Clin. Investig. 2000, 30, 823-831. [CrossRef] [PubMed]

14. Zhang, Z.; Xu, X.; Ni, H.; Deng, H. Predictive Value of Ionized Calcium in Critically Ill Patients: An Analysis of a Large Clinical Database MIMIC II. PLoS ONE 2014, 9, e95204. [CrossRef] [PubMed]

15. Akirov, A.; Gorshtein, A.; Shraga-Slutzky, I.; Shimon, I. Calcium levels on admission and before discharge are associated with mortality risk in hospitalized patients. Endocrine 2017, 57, 344-351. [CrossRef] [PubMed]

16. Jacobs, T.P.; Bilezikian, J.P. Clinical review: Rare causes of hypercalcemia. J. Clin. Endocrinol. Metab. 2005, 90, 6316-6322. [CrossRef]

17. Jeong, J.H.; Bae, E.H. Hypercalcemia Associated with Acute Kidney Injury and Metabolic Alkalosis. Electrolytes Blood Press. 2010, 8, 92-94. [CrossRef]

18. Kohut, B.; Rossat, J.; Raffoul, W.; Lamy, O.; Berger, M.M. Hypercalcaemia and acute renal failure after major burns: An under-diagnosed condition. Burns 2010, 36, 360-366. [CrossRef]

19. Cheungpasitporn, W.; Thongprayoon, C.; Mao, M.A.; Kittanamongkolchai, W.; Sakhuja, A.; Erickson, S.B. Impact of admission serum calcium levels on mortality in hospitalized patients. Endocr. Res. 2018, 43, 116-123. [CrossRef]

20. Miller, J.E.; Kovesdy, C.P.; Norris, K.C.; Mehrotra, R.; Nissenson, A.R.; Kopple, J.D.; Kalantar-Zadeh, K. Association of cumulatively low or high serum calcium levels with mortality in long-term hemodialysis patients. Am. J. Nephrol. 2010, 32, 403-413. [CrossRef]

21. Charlson, M.; Szatrowski, T.P.; Peterson, J.; Gold, J. Validation of a combined comorbidity index. J. Clin. Epidemiol. 1994, 47, 1245-1251. [CrossRef]

22. Levey, A.S.; Stevens, L.A.; Schmid, C.H.; Zhang, Y.L.; Castro, A.F., III; Feldman, H.I.; . Kusek, J.W.; Eggers, P.; Lente, F.V.; Greene, T.; et al. A new equation to estimate glomerular filtration rate. Ann. Intern. Med. 2009, 150, 604-612. [CrossRef] [PubMed]

23. Khwaja, A. KDIGO Clinical Practice Guidelines for Acute Kidney Injury. Nephron 2012, 120, $179-184$. [CrossRef] [PubMed]

24. Ishani, A.; Liu, J.; Wetmore, J.B.; Lowe, K.A.; Do, T.; Bradbury, B.D.; Block, G.A.; Collins, A.J. Clinical Outcomes after Parathyroidectomy in a Nationwide Cohort of Patients on Hemodialysis. Clin. J. Am. Soc. Nephrol. 2014, 10, 90-97. [CrossRef]

25. Sihler, K.C.; Napolitano, L.M. Complications of massive transfusion. Chest 2010, 137, 209-220. [CrossRef]

26. Zhao, Y.; Linden, J.; Welch, L.; Pierre, P.S.; Graves, M.; Garrity, D.; Ducharme, P.; Bailey, J.A.; Greene, M.; Vauthrin, M.; et al. Prophylactic infusion of calcium gluconate to prevent a symptomatic fall in plasma ionized calcium during therapeutic plasma exchange: A comparison of two methods. J. Clin. Apher. 2018, 33, 600-603. [CrossRef]

27. Tse, G.; Chan, Y.W.F.; Keung, W.; Yan, B.P. Electrophysiological mechanisms of long and short QT syndromes. IJC Hear. Vasc. 2017, 14, 8-13. [CrossRef]

28. Hurley, K.; Baggs, D. Hypocalcemic cardiac failure in the Emergency Department. J. Emerg. Med. 2005, 28, 155-159. [CrossRef]

29. Suzuki, T.; Ikeda, U.; Fujikawa, H.; Shimada, K.; Saito, K. Hypocalcemic heart failure: A reversible form of heart muscle disease. Clin. Cardiol. 2009, 21, 227-228. [CrossRef]

30. Kazmi, A.S.; Wall, B.M. Reversible Congestive Heart Failure Related to Profound Hypocalcemia Secondary to Hypoparathyroidism. Am. J. Med. Sci. 2007, 333, 226-229. [CrossRef]

31. Catalano, A.; Basile, G.; Lasco, A. Hypocalcemia: A sometimes overlooked cause of heart failure in the elderly. Aging Clin. Exp. Res. 2012, 24, 400-403. [CrossRef] [PubMed]

32. Wysolmerski, J.J.; Broadus, A.E. HYPERCALCEMIA OF MALIGNANCY: The Central Role of Parathyroid Hormone-Related Protein. Annu. Rev. Med. 1994, 45, 189-200. [CrossRef] [PubMed] 
33. Lutsey, P.L.; Alonso, A.; Michos, E.D.; Loehr, L.R.; Astor, B.C.; Coresh, J.; Folsom, A.R. Serum magnesium, phosphorus, and calcium are associated with risk of incident heart failure: The Atherosclerosis Risk in Communities (ARIC) Study. Am. J. Clin. Nutr. 2014, 100, 756-764. [CrossRef] [PubMed]

34. Chung, J.-W.; Ryu, W.-S.; Kim, B.J.; Yoon, B.-W. Elevated Calcium after Acute Ischemic Stroke: Association with a Poor Short-Term Outcome and Long-Term Mortality. J. Stroke 2015, 17, 54-59. [CrossRef] [PubMed]

35. Kruger, J.M.; Osborne, C.A.; Nachreiner, R.F.; Refsal, K.R. Hypercalcemia and renal failure. Etiology, pathophysiology, diagnosis, and treatment. Vet. Clin. N. Am.-Small Anim. Pract. 1996, 26, 1417-1445. [CrossRef]

36. Baylis, P.H.; Milles, J.J.; Wilkinson, R.; Heath, D.A. Vasopressin Function In Hypercalcaemia. Clin. Endocrinol. 1981, 15, 343-351. [CrossRef]

37. Garofeanu, C.G.; Weir, M.; Rosas-Arellano, M.P.; Henson, G.; Garg, A.X.; Clark, W.F. Causes of reversible nephrogenic diabetes insipidus: A systematic review. Am. J. Kidney Dis. 2005, 45, 626-637. [CrossRef]

38. Thongprayoon, C.; Cheungpasitporn, W.; Mao, M.A.; Sakhuja, A.; Erickson, S.B. Admission calcium levels and risk of acute kidney injury in hospitalised patients. Int. J. Clin. Pract. 2018, 72, e13057. [CrossRef]

39. Thongprayoon, C.; Cheungpasitporn, W.; Mao, M.A.; Harrison, A.; Erickson, S.B. Elevated admission serum calcium phosphate product as an independent risk factor for acute kidney injury in hospitalized patients. Hosp. Pract. 2019, 47, 73-79. [CrossRef]

40. Thongprayoon, C.; Cheungpasitporn, W.; A Mao, M.; Erickson, S.B. Calcium-phosphate product and its impact on mortality in hospitalized patients. Nephrology 2020, 25, 22-28. [CrossRef]

41. Cheungpasitporn, W.; Thongprayoon, C.; Bathini, T.; Hansrivijit, P.; Vaitla, P.; Medaura, J.; Vallabhajosyula, S.; Chewcharat, A.; Mao, M.A.; Erickson, S.B. Impact of admission serum magnesium levels on long-term mortality in hospitalized patients. Hosp. Pract. 2020, 1-6. [CrossRef] [PubMed]

42. Thongprayoon, C.; Cheungpasitporn, W.; Chewcharat, A.; A Mao, M.; Vallabhajosyula, S.; Bathini, T.; Thirunavukkarasu, S.; Kashani, K.B. Risk of respiratory failure among hospitalized patients with various admission serum potassium levels. Hosp. Pract. 2020, 1-5. [CrossRef] [PubMed]

43. Thongprayoon, C.; Cheungpasitporn, W.; Hansrivijit, P.; Thirunavukkarasu, S.; Chewcharat, A.; Medaura, J.; A Mao, M.; Kashani, K.B. Association of serum magnesium level change with in-hospital mortality. BMJ Evid.-Based Med. 2020. [CrossRef] [PubMed]

44. Thongprayoon, C.; Cheungpasitporn, W.; Hansrivijit, P.; Thirunavukkarasu, S.; Chewcharat, A.; Medaura, J.; A Mao, M.; Kashani, K. Association of serum chloride level alterations with in-hospital mortality. Postgrad. Med. J. 2020. [CrossRef]

45. Thongprayoon, C.; Cheungpasitporn, W.; Hansrivijit, P.; Mao, M.A.; Medaura, J.; Bathini, T.; Chewcharat, A.; Erickson, S. Admission Serum Potassium Levels in Hospitalized Patients and One-Year Mortality. Medicines 2019, 7, 2. [CrossRef]

46. Thongprayoon, C.; Cheungpasitporn, W.; Chewcharat, A.; Mao, M.A.; Thirunavukkarasu, S.; Kashani, K.B. Admission serum phosphate levels and the risk of respiratory failure. Int. J. Clin. Pract. 2020, 74, e13461. [CrossRef]

(C) 2020 by the authors. Licensee MDPI, Basel, Switzerland. This article is an open access article distributed under the terms and conditions of the Creative Commons Attribution (CC BY) license (http://creativecommons.org/licenses/by/4.0/). 